\title{
Üniversite Öğrencilerinin Turizm Algısı: Van Yüzüncü Yıl Üniversitesi Örneği ${ }^{1}$
}

\author{
Sağbetullah MERİÇ \\ Dr. Öğr. Üyesi, Van Yüzüncü Y1l Üniversitesi, Turizm Fakültesi \\ smeric@yyu.edu.tr \\ Orcid ID: https://orcid.org/0000-0003-1949-623X

\section{Şilan ERTEN} \\ Yüksek Lisans Öğrencisi, Van Yüzüncü Yıl Üniversitesi, \\ Sosyal Bilimler Enstitüsü, Turizm İşletmeciliği Ana Bilim Dalı \\ silanerten@gmail.com \\ Orcid ID: https://orcid.org/0000-0003-2107-7341
}

\begin{abstract}
Öz
Van ili sahip olduğu kültürel ve tarihi değerleri ile turizm için ilgi çekici bir destinasyon konumundadır. Bu destinasyonu daha ileri bir konuma taşıyabilmek için paydaşların turizm algısı belirlenmeli ve önemsenmelidir. Bu çalışmada, Van Yüzüncü Y1l Üniversitesi öğrencilerinin Van'ın turizm algısı hakkındaki görüş ve düşünceleri belirlenmeye çalışılmıştır. Veri elde etmek için öğrencilere 385 anket uygulanmıştır. Öğrencilerin turizm algısını ölçmek için hazırlanan ankette olumlu ve olumsuz turizm algisı olmak üzere toplam 27 ifade bulunmaktadır. Öğrencilerin çoğunluğu turizmin olumlu sonuçları olduğuna dair ifadelere katılıyorum şeklinde görüş bildirmiştir. Araştırma sonucunda elde edilen bulgular doğrultusunda ilgililere öneriler sunulmuştur.
\end{abstract}

Anahtar Kelimeler: Turizm Alg1s1, Van Yüzüncü Y1l Üniversitesi, Van, Turizm.

\footnotetext{
${ }^{1}$ Makale Geliş/Kabul Tarihi: 25.01.2019 / 20.04.2020

Künye Bilgisi: Meriç, S. ve Erten, Ş. (2020). Üniversite Öğrencilerinin Turizm Algısl: Van Yüzüncü Yll Üniversitesi Örneği. Kahramanmaraş Sütçü İmam Üniversitesi Sosyal Bilimler Dergisi, 17(1), 420-440. DOI: 10.33437/ksusbd.517956
} 


\title{
Tourism Perception of University Students: The Case of Van Yüzüncü Yıl University
}

\begin{abstract}
Van city is an attractive destination for tourism with its cultural and historical values. In order to carry this destination to a more advanced position, the perception of tourism should be determined and considered. In this study, Van Yüzüncü Yil University students' thoughts and thoughts about Van's perception of tourism were tried to be determined. 385 questionnaires were applied to the students to obtain data. The questionnaire prepared to measure the tourism perception of the students has a total of 27 statements, positive and negative. The majority of the students stated that they agree with the expressions of the positive results of tourism. In accordance with the findings of the study, suggestions were presented to the related parties.
\end{abstract}

Keywords: Tourism Perception, Van Yüzüncü Yıl University, Van, Tourism.

\section{GİRIS}

Turizm sektörü dünyada gelişen ve küreselleşmeyle birlikte rekabetin de hızla arttığı bir sektördür. Artan rekabet kapsamında turizm ülke, bölge ve yöreleri kendi aralarında rekabete girerek, bölgesel kalkınmanın sağlanabilmesi adına değişik plan ve projeler gerçekleştirme gayreti içerisine girerler. Yapılan ekonomik planlamalar ve projelerin yanı sıra bölgedeki insanların tutum ve davranışları da önemli bir etkendir (Long ve Richardson, 1989). Yani turizmin etkileri sadece ekonomik sonuçları değil ekonomik olmayan sosyal ve kültürel konuların da irdelenmesini gerektirir (Civelek, 2010: 333).

Kaynaklara dayalı bir endüstri olan turizm, kendisini besleyen doğal kaynakları korumakla beraber bu kaynakları tahrip edebilecek bir karaktere de sahiptir (Cook, Hsu, ve Marqua, 2016). Bu nedenle sürdürülebilirlik algısı turizm endüstrisinde de yaygın ve geniş bir uygulama alanına sahiptir (Arslan Kalay, Şahin ve Meriç, 2017). Turizm algısı kapsamında yapılan araştırmalarda turizmin olumlu sonuçlarının yanında turizmin olumsuz sonuçları algısı da yer almaktadır. 
$\mathrm{Bu}$ araştırmada üniversite öğrencilerinin Van ili turizmine ilişkin turizmin olumlu ve olumsuz sonuçlarına dair algıları belirlenmeye çalışılmıştır. Van'da üniversite okuyan yaklaşık otuz bin öğrenci olması ve bu öğrencilerin Van turizminin geleceğinde etkili olacağ düşüncesi gibi nedenlerle araştırma evrenini öğrenciler oluşturmaktadır. Çünkü bu öğrencilerin çoğu farklı şehirlerden gelerek Van turizmi hakkında belli bir algıya sahiptir. Araştırmanın, literatüre katkı sağlayacağı düşünülmektedir. $\mathrm{Bu}$ kapsamda yapılmış yeterince araştırma olmaması ve araştırmanın geleceğe yönelik sağlayacağı katkı araştırmayı önemli k1lmaktadır.

\section{LITERATÜR İNCELEMESI}

Turizmin ilk tanımı Guyer-Feuler tarafından 1905 yılında ortaya atılmıştır. Turizm, yaşanan hava değişimi, insanların dinlenme ihtiyaçları, doğal güzellikleri görme isteğine bağlı olarak sanayi ekonomisinin gelişmesi ile ulaşımın kolay hale gelmesi sonucunda toplumların ve kültürlerin yakınlaşmas ile ortaya çıkan modern çağa özgü olaydır. Turizm 1981 yılında AIEST (Uluslararası Bilimsel Turizm Uzmanları Birliği) tarafından yapılan tanıma göre, insanların yaşamlarını sürdürdükleri bölgelerin dışına seyahat ederek, gittikleri bölgelerde, yeme-içme, eğlence, spor gibi ihtiyaçlarının karşılandığı, geçici konaklamalarından oluşan ilişkiler bütünüdür (Kozak,2012: 6).

17. yüzyılda Fransa'da ilk rehberli gezi düzenlenmiştir. Bu gezi rehberi tur sözcüğünü turizm diline yerleştirmiştir. Bu sözcük, o dönemde Paris Merkez olmak üzere başka mekân ve merkezlere yapılan seyahatler anlamında kullanılıyordu. Tur sözcügü İngiltere de anlam değiştirerek Avrupa'ya yapılan seyahatler için kullanılmaya başlandı. İngiltere'den Avrupa kıtasına yapılan seyahatlere soyluların katılmasıyla bu süreç, anlam ve içerik olarak değişti. O dönemde Avrupa kıtasına gidenleri, yurt içinde seyahat edenlerden ayırmak için bunlara "tourist'" denilmiştir (Eralp,1983: 8).

Alg1, zihinsel süreçlere bağlı, algılanan nesnenin uyarıcılar tarafından yorumlanması ile oluşan süreçtir. Aynı uyarıcıların insanlar tarafından farklı yorumlanması kültür, beklenti gibi çeşitli faktörlerden kaynaklanır (Bilgin ve Özdemir, 2013: 27). Algılama, bir nesnenin beş duyu organın uyarılması ile zihinsel yapıda belirlenmesi ve yorumlanmasıdır (Akova, 2006). Algılar, insan zihninde çeşitli problemler oluşturmakta ve bu problemlere çözüm üretmektedir. Alg1, başlangıçta edinilen bilgiyi, insanların hareketlerini güdülerini zihinde sınıflandırarak ve ek bilgiler geldikçe bu bilgileri güncelleyerek sosyal algılama faaliyetini gerçekleştirir. Turizm algısı ile de kişilerin turizm faaliyeti hakkında deneyim veya başka şekillerde elde edinilen bilgi ve düşünceler ifade edilmektedir. 
Yerel halkın turizme yaklaşımı, o bölgenin veya şehrin gelişiminde önemli bir yere sahiptir (Alaeddinoğlu, 2008). Yerel halkın olumlu tutum içerisinde olmadığı, turizmin desteklenmediği bölgelerde gelişim yeterince sağlanmayacaktır (Sheldon ve Var, 1984). Bu durum üniversite öğrencileri için de geçerlidir. Şehirde hem yerel halk hem de ziyaretçi konumunda olan üniversite öğrencilerinin algısı turizmin gelişmesinde etkili olabilecek bir durumdur.

İnsanların turizm algısı, farklı etkilerin algılanmasıyla değişiklik gösterir. Sosyal, kültürel, ekonomik ve çevresel etkiler turizm algısını oluşturur (Türker, 2014: 82). Etkilerin toplamı, toplam turizm etkisini oluşturur bu da turizme olan destekle ilişkilidir. Yerel halk ya da şehirdeki öğrenciler turizmin etkisinin olumlu yönde olacağ 1 inancındaysa, turizm gelişimine katk1 sağlayacaktır. Turizmin ekonomik yararı, bu kesimler tarafından benimsenen en önemli etkidir. Bunun nedeni turizmin istihdam faydasıdır (Cengiz ve Kırkbir, 2007: 20).

\section{Turizmin Ekonomik, Sosyo-Kültürel ve Çevresel Etkisi}

Turizmin etkisi genellikle üç grupta ele alınmaktadır. Bunlardan birincisi ekonomik etki, ikincisi sosyo-kültürel etki üçüncüsü ise çevresel etkidir (Okuyucu ve Somuncu, 2012: 38). Turizm, ekonomik olarak pek çok ülkeye fayda sağlayan bir sektördür. Turizm, gelişmekte olan ülkelere döviz girdisi sağlamak ve istidam olanakları oluşturmak yoluyla ülke kalkınmasında rol oynar. (De Kadt, 1979). Yabancı turistlerin tüketim yerlerine gelerek döviz bırakması, yurt dışına hiçbir malın satılmadan ihracat yapılması anlamına gelmektedir (Zengin, 2010: 105). Sektörde yapılan yatırımlar ekonomik faaliyet sağlamakla birlikte bölgede hem istihdam sağlamakta hem de diğer sektörlerin canlanmasına katkıda bulunmaktadır (Kozak, 2012;91).

Turizm farklı sosyal yapıdaki toplumların birbiriyle etkileşim sağlamasında önemli bir araçtır. Bu etkileşim bazı değişmelere neden olabilmektedir (Goeldner ve Ritchie, 2009). Bu değişmeler toplumun benimseyemeyeceği olaylara ve bölgenin turizm yaşamının sona ermesine sebep olabilir. Bir bölgede turistlerin olması, yerli halkı etkilemektedir. Ziyaretçiler gittiği bölgelerde de yerel halkın kültürel yapısından etkilenebilmektedir (Civelek, 2010: 33)

Bir bölgeye turizm talebinin oluşmasında o bölgenin sahip olduğu çevresel faktör önemli bir yere sahiptir. Turistlerin gidecek yerleri seçmesinde çevre belirleyici öğedir (Inskeep, 1991). Turizmin çevrenin korunmasına yönelik katkıları bulunmaktadır. Turizm, tarihi yapıların restorasyonunda önemli bir etken olmaktadır. Turizm talebinin oluşmasında tarihi yapıtlar çekim öğesi olarak kullanılmaktadır. Eski yapıtların, yeni kimlikleriyle yaşamlarını sürdürmeleri hanların, sarnıçların restoran otel olarak dönüştürmesi ziyaretçilerin ilgisini çekmektedir. Turizm çevrenin korunmasına önem vermektedir. Ulusal parklar, koruma alanları tarihi yapıların korunmasına yönelik politikalar 
gerçekleştirilmiştir (Kozak, 2012: 114). Ancak bu belirtilen olumlu özelliklerin yanında kültür yozlaşması, altyapının yetersiz kalması, tarihi değerlerin tahrip edilmesi gibi olumsuz sonuçlar da meydana gelebilir.

\section{Van İlinin Sahip Olduğu Turizm Potansiyeli}

Van birçok medeniyete ev sahipliği yapmış, bu medeniyetlere ait izler taşımaktadır. Tilkitepe ve Dilkaya Höyükleri neolitik devirden izler taşımakta ve Urartulardan birçok eser barındırmaktadır. Van kalesi en önemli eserlerdendir. Bölgenin en önemli eserlerinden Akdamar kilisesi Vaspurakan Krallığına aittir. $\mathrm{Bu}$ dönemden itibaren Hıristiyan etkileri mimari yapılarda görülmeye başlanmıştır. Malazgirt savaşıyla Selçukluların toprağına katılmış ve İslam etkileri bütün eserlerde yer edinmiştir (www.vankulturturizm.gov.tr).

İnanç turizmi kapsamında uluslararası boyutta önemli bir yere sahip ve haç merkezi konumunda olan Akdamar Adası turizm konusunda önemli bir değerdir. Saray kompleksinin kilisesi olarak inşa edilen bu yapı günümüze kadar ulaşmayı başarırken, saray ve liman Van Gölü'nün yükselmesi sonucu sular altında kalarak yok olmuştur (Arslan Kalay ve Yıldız, 2017). Kıyıya üç kilometre uzaktaki Akdamar Adasında bulunan bu tarihi yapı duvarlarında, Tevrat ve İncil'den alınan dini konular, günlük olaylar ve av sahneleri taş kabartma şeklinde yer almaktadır (Kaya, Cankül ve Demirci, 2013).

Türkiye'nin en büyük gölü olan Van gölünde yazları sıcak ve kurak, kışları soğuk ve yağışlı bir iklim görülür. Van gölü kıyı turizmi açısından önemli bir potansiyele sahiptir. Bunun yanında, Van gölü su sporları açısından da önemli bir yere sahiptir. Rüzgâr sörfü, dalga sörfü, su kayağ 1 yelken turizmi gibi sporlar Van gölü sahilinde yapılabilmektedir (Meriç ve Bozkurt, 2017:160). Van gölü suyunun ciltte olumlu etkilerinin olması diğer bir önemli husustur. Van gölü suyunda bulunan bikarbonat değeri kaplıca sularından ortalama yirmi kat daha yüksektir. Bikarbonatlı sular, sağlıklı olduğundan dolayı içme veya banyo için kullanılmaktadır (Odabaşı ve Tekbaş, 2015: 72).

Bölgenin etrafının yüksek dağlarla çevrili olması, kar kalitesinin yüksek olması kış sporları açısından, bölgeyi avantajlı hale getirmektedir. Van'da iki adet kayak merkezi bulunmaktadır, bu kayak merkezleri Gürpınar Kurubaş kayak merkezi ve Gevaş Abalı kayak merkezidir. Van birçok festivale ev sahipliği yapmaktadır. Bunlardan bazıları; İnci Kefali Göçü Festivali, Flamingo Festivali, Çatak Bal-Ceviz ve Kültür Festivalidir. Gastronomi açısından bakılacak olursa, Van yöresi oldukça zengin mutfağa sahiptir. Van mutfağını oluşturan en önemli kısım ise kahvaltıdır. Van kahvaltısı, bölgenin ismini duyurmasındaki en önemli faktörlerden biridir (Daka, 2013). 
S.Meric - S.Erten $\quad$ Üniversite Öğrencilerinin Turizm Algısı: Van...

\section{METODOLOJí}

\section{Araștırmanın Amacı ve Önemi}

Bu araştırmada, Van Yüzüncü Yıl Üniversitesi öğrencilerinin Van'ın turizm faaliyetleri ve turizm potansiyeline ilişkin algıları belirlenmeye çalışılmıştır. $\mathrm{Bu}$ doğrultuda araştırmanın amacı, üniversite öğrencilerinin Van ili turizm faaliyetleri hakkındaki algılarını belirlemektir. Araştırma kapsamında öğrencilerin algısının belirlenmesi amaçlandığından öğrencilerin neden bu algıya sahip oldukları veya bu algının doğru olup olmadığı dikkate alınmamıştır. Araştırma sonucunda üniversite öğrencilerinin turizm gelişmelerinden nasıl etkilendiği de açıklanmıştır. Araştırmada öğrencilerin turizmin ekonomik, sosyal ve çevresel etkilerine ilişkin algılarının; cinsiyet, okunan fakülte, ikamet süreleri ve yaş gibi değişkenlere göre farklılık gösterip göstermediği de incelenmiştir.

Turizm sektörü dünyanın en önde gelen ve en hızlı büyüyen sektörlerinden birisi olarak kabul edilmektedir. Bu nedenle turizm alanında dinamik değişimi takip etme yerine, bu değişime yön verme çabası içerisinde olmak gerekir (Iş̧1k ve Meriç, 2015: 3). Bu nedenle insanların turizm konusundaki algıları şehirlerin, bölgelerin hatta ülke turizm stratejilerinin oluşmasını ve uygulanmasını etkiler. $\mathrm{Bu}$ araştırma, şehirlerde önemli bir paydaş olarak kabul edilen üniversite öğrencilerinin turizm algısını belirlemesi yönüyle önem arz etmektedir.

\section{Araştırmanın Yöntemi ve Kısıtları}

$\mathrm{Bu}$ çalışma, nicel araştırma yöntemi tasarımında gerçekleştirilmeye çalışılmış bir araştırmayı içermektedir. Araştırmada veri toplamak için anket formu kullanılmıştır. Anket formu iki bölümden oluşmaktadır. İlk bölümde cinsiyet, babanın ve annenin eğitim durumu, fakülte, bölüm, aylık harcama, ikamet süresi, yaş ve turizm işletmelerinde çalıştınız $\mathrm{m} 1$ gibi sorular bulunmaktadır. İkinci bölümde ise turizmin gelişimiyle ilgili 27 ifadeye yer almaktadır. İkinci bölümde kullanılan ifadeler Toprak (2015) tarafından geliştirilen anket formundan alınmıştır.

$\mathrm{Bu}$ araştırmada yalnızca anket ile veri elde edilmiş ve kullanılmıştır. $\mathrm{Bu}$ araştırma ile yalnızca Van Yüzüncü Yıl Üniversitesindeki öğrencilerin algılarındaki turizmin olumlu ve olumsuz sonuçları araştırılmıştır. Bu algının oluşmasında etkili olan unsurlar ve bu algının ortaya çıkardığı sonuçlar çalışma konusu dışında kalmaktadır. Bu durum çalışmanın belirgin bir şekilde kısıtlarını oluşturmaktadır. 


\section{Araştırmanın Evreni ve Örneklemi}

Araştırmanın evrenini, 2018-2019 yılında Van Yüzüncü Y1l Üniversitesinde kayıtlı öğrenciler oluşturmaktadır. Üniversitede 15821 Lisans, 7757 Ön lisans, 4954 Lisansüstü, 1912 Pedagojik Formasyon olmak üzere toplamda 30.406 öğrenci eğitim-öğretim görmektedir. Üniversiteye kayıtlı bütün öğrencilere ulaşmak hem zaman hem de imkân açısından mümkün olmadığından örneklem seçimine gidilmiştir. Basit tesadüfi örneklem yöntemi ile 385 öğrenciden anket toplanmıştır. Katılımcıların anket doldurmak istememesi, katılımcıların Van ili turizm potansiyeli hakkında yeterince bilgi sahibi olmadığını belirtmesi, bazı anketlerde hızlı bir şekilde aynı kodların işaretlenmesi, anketlerin yarım doldurulması ve bazı anketlerin araştırmacılara geri teslim edilmemesi gibi nedenler ile daha fazla anket toplanmaya çalışılsa da bu mümkün olmamıştır. Sorunlu anketler çıkarılarak analizler 385 anket ile gerçekleştirilmiştir. $\mathrm{Bu}$ örneklem sayısı evreni temsil edebilecek büyüklüktedir.

\section{BULGULAR}

Üniversite eğitimi alan öğrencilerin turizme bakış açılarının belirlenmesine yönelik ifadeler, öncelikle faktör analizi ve güvenirlik analizine tabii tutulmuştur. Kullanılan ölçek olumlu ve olumsuz turizm algısı şeklinde iki faktörden oluşmaktadır. Yapılan faktör analizi sonucunda ifadelerin doğru faktörü temsil ettiği görülmüş̧ür. Cronbach Alpha değerine bakıldığında bu değerin 0,821 olarak hesaplandığ görülmüş̧ür. Bu değerin 0,70'ten büyük olmas1 yeterli kabul edilmektedir.

Araştırmaya katılanların demografik özelliklerini içeren bilgiler Tablo 1'de sunulmuştur. Demografik özellikler frekans ve yüzde dağılımları ile tabloda yer almaktadır.

Tablo 1. Araştırmaya Katılanların Demografik Özelliklerine İlişkin Bulgular

\begin{tabular}{|l|l|c|c|}
\hline $\begin{array}{c}\text { Demografik } \\
\text { ozzellikler }\end{array}$ & & Frekans & Yüzde \\
\hline \multirow{2}{*}{ Cinsiyet } & Kadın & 201 & 52.2 \\
\cline { 2 - 4 } & Erkek & 184 & 47,8 \\
\hline \multirow{4}{*}{ Yaş } & 18 yaş altı & 3 & 0,8 \\
\cline { 2 - 4 } & $18-20$ & 134 & 34,8 \\
\cline { 2 - 4 } & $21-23$ & 194 & 50,4 \\
\cline { 2 - 4 } & $24-28$ & 49 & 12,7 \\
\cline { 2 - 4 } & 28 ve üzeri & 5 & 1,3 \\
\hline \multirow{2}{*}{$\begin{array}{c}\text { Turizm sektörü } \\
\text { deneyimi }\end{array}$} & Var & 48 & 12,5 \\
\cline { 2 - 4 } & Yok & 337 & 87,5 \\
\hline
\end{tabular}


S.Meric - S.Erten Üniversite Öğrencilerinin Turizm Algısı: Van...

\begin{tabular}{|c|c|c|c|}
\hline \multirow{4}{*}{ Van da ikamet süresi } & 1 yildan az & 79 & 20,5 \\
\hline & $1-3$ yil & 114 & 29,9 \\
\hline & $3-6$ & 77 & 20,0 \\
\hline & 6 yıldan fazla & 115 & 29,9 \\
\hline \multirow{5}{*}{ Aylık harcama } & 500 ve alt1 & 189 & 49,1 \\
\hline & $500-1000$ & 132 & 34,3 \\
\hline & $1000-1500$ & 42 & 10,9 \\
\hline & $1500-2000$ & 12 & 3,1 \\
\hline & 2000 ve üzeri & 9 & 2,3 \\
\hline \multirow{5}{*}{$\begin{array}{l}\text { Babanızın eğitim } \\
\text { durumu }\end{array}$} & İlköğretim & 243 & 63,1 \\
\hline & Lise & 75 & 19,5 \\
\hline & Ön lisans & 16 & 4,2 \\
\hline & Lisans & 32 & 8,3 \\
\hline & Yüksek lisans ve doktora & 8 & 2,1 \\
\hline \multirow{5}{*}{$\begin{array}{l}\text { Annenizin eğitim } \\
\text { durumu }\end{array}$} & İlköğretim & 266 & 69,1 \\
\hline & Lise & 33 & 8,6 \\
\hline & Ön lisans & 9 & 2,3 \\
\hline & Lisans & 5 & 1,3 \\
\hline & Yüksek lisans ve doktora & 2 & 0,5 \\
\hline \multirow{17}{*}{ Fakülte } & Edebiyat Fakültesi & 63 & 16,4 \\
\hline & İlahiyat Fakültesi & 40 & 10,4 \\
\hline & $\begin{array}{l}\text { İktisadi İdari Bilimler } \\
\text { Fakültesi }\end{array}$ & 100 & 26,0 \\
\hline & Eğitim Fakültesi & 32 & 8,3 \\
\hline & Fen Fakültesi & 23 & 6,0 \\
\hline & $\begin{array}{l}\text { Sağlık Hizmetleri } \\
\text { Yüksekokulu }\end{array}$ & 9 & 2,3 \\
\hline & Sağlık Yüksekokulu & 17 & 4,4 \\
\hline & $\begin{array}{l}\text { Turizm Otelcilik } \\
\text { Yüksekokulu }\end{array}$ & 16 & 4,2 \\
\hline & Veterinerlik Fakültesi & 9 & 2,3 \\
\hline & Sağlık Meslek Yüksekokulu & 11 & 2,9 \\
\hline & Ziraat Fakültesi & 9 & 2,3 \\
\hline & T1p Fakültesi & 6 & 1,6 \\
\hline & Mühendislik Fakültesi & 27 & 7,1 \\
\hline & Eczacılık Fakültesi & 7 & 1,8 \\
\hline & Van Meslek Yüksekokulu & 5 & 1,3 \\
\hline & Diş Hekimliği Fakültesi & 5 & 1,3 \\
\hline & BESYO & 6 & 1,6 \\
\hline
\end{tabular}


Araştırmaya katılan 385 kişinin büyük çoğunluğunu \%52,2 (201 kişi) ile kadınlar oluşturmaktadır. Ancak araştırmaya katılan kadın ve erkek oranlarının birbirine oldukça yakın olduğu görülmektedir. Katılımcıların yaş dağılımlarına bakıldığında, katılımcıların \%0,8'i (3kişi) 18 yaşından küçük, \%34,8'i (134 kişi) 18 ile 20 yaş arasında, \%50,4'ü (194 kişi) 21 ile 23 yaş arasında, \%12,7'si (49 kişi) 24 ile 28 yaş arasında, \%1,3'ü ise (5 kişi) 28 ve üzeri yaş aralığındadır. Katılımcıların büyük çoğunluğu, 21-23 yaş aralığında yer almaktadır. Araştırmaya katılanların \% 87,5'inin turizm sektörü deneyimi yokken yalnızca 48 kişinin turizm sektöründe çalışma deneyimi vardır. Araştırmaya katılan kişilerin \%20,5 i (79 kişi) 1 yıldan az, \%29,9'u (114 kişi)1 ila 3 yıl arası, \%20'si (77 kişi) 3 ile 6 y1l arası, \%29,9'u (115 kişi) ise 6 yıldan fazla süredir Van ilinde ikamet etmektedir. Van'lı öğrencilerin de araştırmaya katıldığı dikkate alındığında araştırmaya katılan öğrencilerin büyük çoğunluğunun Van ili dışında yaşadıkları anlaşı1maktadır. Araştırmaya katılan kişilerin \% 49,1'i (189 kişi) 500 TL ve altında, \%34,3 ‘ü (132 kişi) $500 \mathrm{TL}$ - $1000 \mathrm{TL}$ arasında, \%10,9’u (42kişi) 1000 TL ile 1500 TL arasında, \%3,1 'i (12 kişi) 1500 TL ile 2000 TL arasında, \%2,3'ü (9 kişi) ise 2000 TL ve üzeri aylık harcama yapmaktadır. Araştırmaya katılan kişilerin babalarının \% 63,1'i (243 kişi) ilköğretim, \% 19,5'i (75 kişi) lise, \% 4,2'si (16 kişi) ön lisans, \%2,1'i (8 kişi) yüksek lisans ve doktora eğitimi görmüştür. Araştırmaya katılan kişilerin annelerinin \% 69,1'i (266 kişi) ilköğretim, \% 8,6 ‘sı (33 kişi) lise, \% 2,3'ü (9 kişi) ön lisans, \% 1,3'ü (5 kişi) lisans ve \% 0,5'i (2 kişi) ise yüksek lisans ve doktora eğitimi görmüştür. Araştırmaya katılan kişilerin okudukları fakülteye göre dağılımları dikkate alındığında üniversite kapsamındaki tüm fakültelerin öğrencilerine ulaşılmaya çalışıldığ görülmektedir. Katılımcıların \%16,4'ü (63 kişi) edebiyat fakültesi, \% 10,4'ü (40 kişi) ilahiyat fakültesi, \% 26's1 (100 kişi) İ.İ.B.F, \% 8,3’ü (32 kişi) eğitim fakültesi, \% 6 'sı (23 kişi) fen fakültesi, \% 2,3’ü (9 kişi) sağlık hizmetleri yüksekokulu, \% 4,4'ü (17 kişi) sağlık yüksek okulu, \% 4,2'si (16 kişi) turizm otelcilik yüksekokulu, \% 2,3’ü (9 kişi) veterinerlik fakültesi, \%2,9'u (11 kişi) sağlık meslek yüksek okulu, \%2,3'ü (9 kişi) veterinerlik fakültesi, \%1,6's1 (6 kişi) tıp fakültesi, \% 7,1'i (27kişi) mühendislik fakültesi, \% 1,8'i (7 kişi) eczacılık fakültesi, \% 1,3’ü (5 kişi) meslek yüksekokulu, \% 1,3’ü (5 kişi) diş hekimliği, \% 1,6 's1 (6 kişi) beden eğitimi ve spor yüksekokulu öğrencisidir.

Tablo 2. Katılımcıların Turizmin Olumlu Sonuçlarına Yönelik Algıları

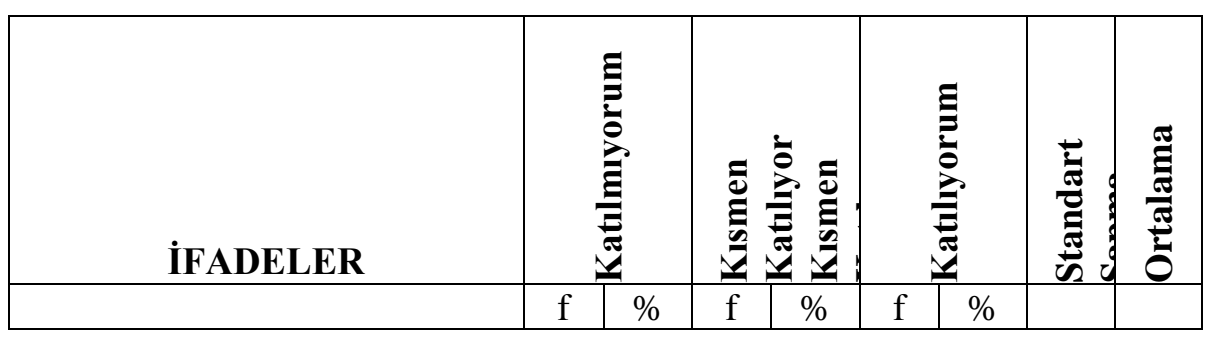




\begin{tabular}{|c|c|c|c|c|c|c|c|c|}
\hline $\begin{array}{l}\text { Turizm, Van'ın gelişiminde en } \\
\text { önemli sektör olacaktır. }\end{array}$ & 74 & $\begin{array}{c}19 \\
2\end{array}$ & 54 & $\begin{array}{c}14 \\
0\end{array}$ & $\begin{array}{c}25 \\
7 \\
\end{array}$ & $\begin{array}{c}66, \\
8\end{array}$ & $\begin{array}{c}1,2 \\
3\end{array}$ & $\begin{array}{c}3,7 \\
2\end{array}$ \\
\hline $\begin{array}{l}\text { Turizm, insanların gelirlerini } \\
\text { artıracaktır. }\end{array}$ & 46 & $\begin{array}{c}11 . \\
9\end{array}$ & 37 & 9,6 & $\begin{array}{c}30 \\
2\end{array}$ & $\begin{array}{c}78, \\
4\end{array}$ & $\begin{array}{c}1,1 \\
2\end{array}$ & $\begin{array}{c}3,9 \\
7\end{array}$ \\
\hline $\begin{array}{l}\text { Turizm, pek çok insana iş } \\
\text { olanağ1 sağlayacaktır. }\end{array}$ & 49 & $\begin{array}{c}12 \\
7\end{array}$ & 42 & $\begin{array}{c}10 \\
9\end{array}$ & $\begin{array}{c}29 \\
3\end{array}$ & $\begin{array}{c}76, \\
1\end{array}$ & $\begin{array}{c}1,1 \\
5\end{array}$ & $\begin{array}{c}3,9 \\
4\end{array}$ \\
\hline $\begin{array}{l}\text { Turizm ile yerel } \\
\text { kültürler tanıyıp, } \\
\text { sağlanacaktır. }\end{array}$ & 50 & $\begin{array}{c}13 \\
0\end{array}$ & 54 & $\begin{array}{c}14 \\
0\end{array}$ & $\begin{array}{c}28 \\
0\end{array}$ & $\begin{array}{c}72, \\
7\end{array}$ & $\begin{array}{c}1,1 \\
5\end{array}$ & $\begin{array}{c}3,9 \\
0\end{array}$ \\
\hline $\begin{array}{l}\text { Turizm, ildeki tarihi yapıların } \\
\text { restorasyonunu sağlayacaktır. }\end{array}$ & 50 & $\begin{array}{c}13 \\
0\end{array}$ & 62 & $\begin{array}{c}16 \\
1\end{array}$ & $\begin{array}{c}27 \\
2\end{array}$ & $\begin{array}{c}70, \\
6\end{array}$ & $\begin{array}{c}1,1 \\
7\end{array}$ & $\begin{array}{c}3,8 \\
7\end{array}$ \\
\hline $\begin{array}{l}\text { Turizm doğal çevrenin } \\
\text { korunmasını teşvik edecektir. }\end{array}$ & 84 & $\begin{array}{c}21 \\
8\end{array}$ & 78 & $\begin{array}{c}20 \\
3\end{array}$ & $\begin{array}{c}22 \\
2\end{array}$ & $\begin{array}{c}57 \\
7\end{array}$ & $\begin{array}{c}1,2 \\
6\end{array}$ & $\begin{array}{c}3,5 \\
3\end{array}$ \\
\hline $\begin{array}{l}\text { Turizmin gelişimi ildeki } \\
\text { hizmet kalitesini artıracaktır. }\end{array}$ & 56 & $\begin{array}{c}14 \\
5\end{array}$ & 58 & $\begin{array}{c}15 \\
1\end{array}$ & $\begin{array}{c}26 \\
8\end{array}$ & $\begin{array}{c}69, \\
6\end{array}$ & $\begin{array}{c}1,1 \\
2\end{array}$ & $\begin{array}{c}3,8 \\
3\end{array}$ \\
\hline $\begin{array}{l}\text { Turizm, ilin alt yap1 ve üst yap1 } \\
\text { sorunlarının çözümüne katk1 } \\
\text { sağlayacaktır. }\end{array}$ & 57 & $\begin{array}{c}14 \\
8\end{array}$ & 99 & $\begin{array}{c}25 \\
7\end{array}$ & $\begin{array}{c}22 \\
9\end{array}$ & $\begin{array}{c}59, \\
5\end{array}$ & $\begin{array}{c}1,1 \\
0\end{array}$ & $\begin{array}{c}3,6 \\
1\end{array}$ \\
\hline $\begin{array}{l}\text { da ki kültürel } \\
\text { aktır. }\end{array}$ & 47 & $\begin{array}{c}12 \\
2\end{array}$ & 54 & $\begin{array}{c}14, \\
0\end{array}$ & $\begin{array}{c}28 \\
4\end{array}$ & $\begin{array}{c}73, \\
8\end{array}$ & $\begin{array}{c}1,0 \\
8\end{array}$ & $\begin{array}{c}3,9 \\
1\end{array}$ \\
\hline $\begin{array}{l}\text { lik yapısını } \\
\text { ecektir. }\end{array}$ & 39 & $\begin{array}{c}10 \\
1\end{array}$ & 55 & $\begin{array}{c}14 \\
3\end{array}$ & $\begin{array}{c}29 \\
0\end{array}$ & $\begin{array}{c}75, \\
3\end{array}$ & $\begin{array}{c}1,0 \\
1\end{array}$ & $\begin{array}{c}3,9 \\
5\end{array}$ \\
\hline $\begin{array}{l}\text { Turizmin gelis } \\
\text { yatırımlar da ar }\end{array}$ & 42 & $\begin{array}{c}10 \\
9\end{array}$ & 76 & $\begin{array}{c}19 \\
7\end{array}$ & $\begin{array}{c}26 \\
7 \\
\end{array}$ & $\begin{array}{c}69, \\
4 \\
\end{array}$ & $\begin{array}{c}1,0 \\
5\end{array}$ & $\begin{array}{c}3,8 \\
4 \\
\end{array}$ \\
\hline $\begin{array}{lll}\text { Turizm } & \text { ilin } & \text { ulaşım } \\
\text { imkanlarının } & \text { gelişimine } \\
\text { sunacaktır. } & & \\
\end{array}$ & 57 & $\begin{array}{c}14 \\
8\end{array}$ & 55 & $\begin{array}{c}14 \\
3\end{array}$ & $\begin{array}{c}27 \\
2\end{array}$ & $\begin{array}{c}70 \\
6\end{array}$ & $\begin{array}{c}1,1 \\
2\end{array}$ & $\begin{array}{c}3,8 \\
5\end{array}$ \\
\hline $\begin{array}{l}\text { Turizm ilin kültürel ve sosyal } \\
\text { yapısının } \\
\text { sağlayacaktır. }\end{array}$ & 52 & $\begin{array}{c}13 \\
5\end{array}$ & 54 & $\begin{array}{c}14 \\
0\end{array}$ & $\begin{array}{c}27 \\
9\end{array}$ & $\begin{array}{c}72, \\
5\end{array}$ & $\begin{array}{c}1,1 \\
1\end{array}$ & $\begin{array}{c}3,8 \\
6\end{array}$ \\
\hline $\begin{array}{lcc}\text { Turizmin } & \text { gelişimi } & \text { ile } \\
\text { bölgelerarası } & \text { kalkınma } \\
\text { farklılıkları azalacaktır. }\end{array}$ & $\begin{array}{c}10 \\
2\end{array}$ & $\begin{array}{c}26 \\
5\end{array}$ & $\begin{array}{c}10 \\
4\end{array}$ & $\begin{array}{c}27 \\
0\end{array}$ & $\begin{array}{c}17 \\
9\end{array}$ & $\begin{array}{c}46, \\
5\end{array}$ & $\begin{array}{c}1,2 \\
1\end{array}$ & $\begin{array}{c}3,2 \\
3\end{array}$ \\
\hline
\end{tabular}

Öğrencilerin turizm algısını belirlemek amacı ile beşli likert şeklinde toplanan veriler SPSS programı yardımı ile "katılmıyorum", "kararsızım" ve "katıliyorum" şeklinde 3 grupta frekans ve yüzde olarak tablo 2' de sunulmuştur. İfadelere ait ortalama ve standart sapma değerleri ise beşli likerte göre hesaplanmıştır. "Turizm, Van'ın gelişiminde en önemli sektör olacaktır" ifadesine katılımcıların büyük çoğunluğu (n: 257) katılıyorum yönünde cevap vermiştir. Bu sonuç araştırmaya katılan öğrencilerin turizmin Van ilinin geleceği 
için önemli bir sektör olacağına dair inancının yüksek olduğunu gösterir. "Turizm, pek çok insana iş olanağı sağlayacaktır' ifadesine katılımcıların büyük çoğunluğu (n: 293) katılıyorum cevabı vermiştir. Araştırmaya katılan öğrenciler, turizmin istihdam yaratıcı etkisi olduğu kanaatindedir. "Turizm ile yerel halk farklı kültürler tanıyıp, kaynaşması sağlanacaktır" ifadesine katılımcıların çoğunluğu (n:293) katılıyorum ifadesiyle cevaplamıştır. Araştırmaya katılan ögrenciler, bölgeye gelen farklı toplumlarla yerel halkın etkileşim içinde olacağ 1 inancındadır. "Turizm, ildeki tarihi yapıların restorasyonunu sağlayacaktır" ifadesinde katılımcılar (n:293) katılıyorum ifadesini seçmiştir. Bu sonuç ile araştırmaya katılan öğrencilerin ildeki tarihi eserlere verilen değerin turizm sayesinde artacağı inancında olduğu anlaşılmaktadır. "Turizmin gelişimi ildeki hizmet kalitesini artıracaktır' ifadesine katılımcıların çoğunluğu (n:268) katılıyorum cevabı vermiştir. Araştırmaya katılan öğrencilerin ilde verilen hizmetlerin turizm ile kalite kazanacağına olan kanaatleri bu sonuç ile ifade edilmiştir. "Turizm ilin ekonomik yapısını çeşitlendirip, geliştirecektir" ifadesine katılımcıların çoğunluğu (n: 290) katılıyorum ifadesini cevabı vermiştir. $\mathrm{Bu}$ bulguya göre araştırmaya katılan öğrenciler turizmin bölgedeki ekonomiye katk1 sağlayarak ekonomiyi geliştireceğine inanmaktadırlar. "Turizmin gelişimi ile diğer yatırımlar da artacaktır" ifadesinde katılımcıların çoğunluğu (n:267) katılıyorum ifadesini seçmiştir. Bu sonuç ile araştırmaya katılan öğrenciler, turizmin diğer yatırımların önünü açacağına ve bu yatırımların bölgenin gelişimine etkisi bulunacağına inanmaktadırlar. "Turizm ilin ulaşım imkanlarının gelişimine katkı sunacaktır' ifadesine katılımcıların çoğunluğu (n: 272) katılıyorum cevabı vermiştir. Araştırmaya katılan öğrenciler, turizmin bölgenin ulaşım imkanlarının gelişimine katkı sağlayacağına inanmaktadır. "Turizm ilin kültürel ve sosyal yapısının tanınmasını sağlayacaktır" ifadesine katılımcıların çoğunluğu (n:279) katılıyorum ifadesini cevabı vermiştir. $\mathrm{Bu}$ sonuca göre araştırmaya katılan öğrenciler, bölgenin tanınmasında turizmin önemli rolü olduğu inancındadırlar.

Tablo 3. Katılımcıların Turizmin Olumsuz Sonuçlarına Yönelik Algıları

\begin{tabular}{|c|c|c|c|c|c|c|c|c|}
\hline \multirow[t]{2}{*}{ İFADELER } & \multicolumn{2}{|c|}{ 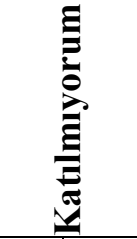 } & \multicolumn{2}{|c|}{ 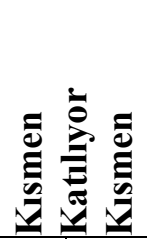 } & \multicolumn{2}{|c|}{ ב } & \multirow[t]{2}{*}{ 预 } & \multirow[t]{2}{*}{ 苞 } \\
\hline & $\mathrm{f}$ & $\%$ & $\mathrm{f}$ & $\%$ & $\mathrm{f}$ & $\%$ & & \\
\hline $\begin{array}{l}\text { Turizm, suç oranlarını } \\
\text { artıracaktır. }\end{array}$ & $\begin{array}{c}19 \\
2 \\
\end{array}$ & $\begin{array}{c}49 \\
9\end{array}$ & 88 & $\begin{array}{c}22 \\
9\end{array}$ & $\begin{array}{c}10 \\
5 \\
\end{array}$ & $\begin{array}{c}27, \\
3\end{array}$ & $\begin{array}{c}1,2 \\
8\end{array}$ & $\begin{array}{c}2,6 \\
4\end{array}$ \\
\hline $\begin{array}{l}\text { Turizm ildeki terör ve diğer } \\
\text { sosyal sorunları arttıracaktır. }\end{array}$ & $\begin{array}{c}21 \\
8\end{array}$ & $\begin{array}{c}56, \\
6\end{array}$ & 83 & $\begin{array}{c}21 \\
6\end{array}$ & 83 & $\begin{array}{c}21, \\
6\end{array}$ & $\begin{array}{c}1,6 \\
6\end{array}$ & $\begin{array}{c}2,4 \\
9\end{array}$ \\
\hline
\end{tabular}




\begin{tabular}{|c|c|c|c|c|c|c|c|c|}
\hline $\begin{array}{lr}\begin{array}{l}\text { Turizm, ildeki } \\
\text { yaşamı } \\
\text { değiștirecektir. }\end{array} & \begin{array}{r}\text { geleneksel } \\
\text { bozacak/ }\end{array} \\
\end{array}$ & $\begin{array}{c}17 \\
2\end{array}$ & $\begin{array}{c}44, \\
7\end{array}$ & 81 & $\begin{array}{c}21 \\
0\end{array}$ & $\begin{array}{c}12 \\
9\end{array}$ & $\begin{array}{l}33, \\
5\end{array}$ & $\begin{array}{c}1,2 \\
9\end{array}$ & $\begin{array}{c}2,7 \\
8\end{array}$ \\
\hline $\begin{array}{l}\text { Turizm, ilde aşırı nüfus artışına } \\
\text { neden olacaktır. }\end{array}$ & $\begin{array}{c}11 \\
7 \\
\end{array}$ & $\begin{array}{c}30 \\
4\end{array}$ & 86 & $\begin{array}{c}22 \\
3\end{array}$ & $\begin{array}{c}18 \\
2 \\
\end{array}$ & 3 & $\begin{array}{c}1,2 \\
5\end{array}$ & $\begin{array}{c}3,2 \\
1\end{array}$ \\
\hline & $\begin{array}{c}16 \\
0\end{array}$ & $\begin{array}{c}41, \\
6\end{array}$ & 82 & $\begin{array}{c}21 \\
3\end{array}$ & $\begin{array}{c}14 \\
2\end{array}$ & $\begin{array}{c}36, \\
9\end{array}$ & $\begin{array}{c}1,3 \\
0\end{array}$ & $\begin{array}{c}2,9 \\
5\end{array}$ \\
\hline $\begin{array}{l}\text { ildeki pek çok mal ve } \\
\text { n fiyat artışına neden } \\
\text { r. }\end{array}$ & 84 & $\begin{array}{c}21 \\
8\end{array}$ & 73 & $\begin{array}{c}19 \\
0\end{array}$ & $\begin{array}{c}22 \\
7\end{array}$ & $\begin{array}{c}59 \\
0\end{array}$ & $\begin{array}{c}1,3 \\
0\end{array}$ & $\begin{array}{c}3,5 \\
7\end{array}$ \\
\hline vre kirliliğine neden & $\begin{array}{c}13 \\
2 \\
\end{array}$ & $\begin{array}{c}34, \\
3\end{array}$ & 87 & $\begin{array}{c}22 \\
6\end{array}$ & 5 & $\begin{array}{c}42 \\
9\end{array}$ & $\begin{array}{c}1,3 \\
1\end{array}$ & $\begin{array}{c}3,0 \\
9\end{array}$ \\
\hline $\begin{array}{l}\text { gürültü kirliliğine } \\
\text { acaktır. }\end{array}$ & $\begin{array}{c}11 \\
7 \\
\end{array}$ & $\begin{array}{c}30 \\
4\end{array}$ & 79 & $\begin{array}{c}20 \\
5\end{array}$ & 18 & $\begin{array}{c}49 \\
1\end{array}$ & $\begin{array}{c}1,3 \\
3 \\
\end{array}$ & $\begin{array}{c}3,2 \\
6 \\
\end{array}$ \\
\hline $\begin{array}{l}\text { erel halk ile turistler } \\
\text { sorunlar yaşamasına } \\
\text { acaktır. }\end{array}$ & $\begin{array}{c}12 \\
6\end{array}$ & $\begin{array}{c}32 \\
7\end{array}$ & $\begin{array}{l}10 \\
5\end{array}$ & $\begin{array}{c}27 \\
3\end{array}$ & $\begin{array}{c}15 \\
4\end{array}$ & 40 & $\begin{array}{c}1,2 \\
7\end{array}$ & $\begin{array}{c}3,1 \\
1\end{array}$ \\
\hline 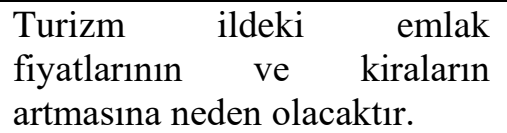 & 63 & $\begin{array}{c}16 \\
4\end{array}$ & 63 & $\begin{array}{c}16 \\
4\end{array}$ & $\begin{array}{c}25 \\
6\end{array}$ & $\begin{array}{c}66 \\
5\end{array}$ & $\begin{array}{c}1,2 \\
6\end{array}$ & $\begin{array}{c}3,7 \\
6\end{array}$ \\
\hline $\begin{array}{l}\text { Turizm ildeki ahlak1 yapıy1 } \\
\text { bozacaktır. }\end{array}$ & $\begin{array}{c}14 \\
1 \\
\end{array}$ & 36 , & & 3 & $\begin{array}{c}13 \\
9 \\
\end{array}$ & & $\begin{array}{l}1,3 \\
7 \\
\end{array}$ & $\begin{array}{c}3,0 \\
0\end{array}$ \\
\hline $\begin{array}{llr}\text { Turizm ildeki } & \text { alkol ve } \\
\text { uyuşturucu } & \text { kullanımını } \\
\text { artıracaktır. }\end{array}$ & $\begin{array}{c}13 \\
2\end{array}$ & $\begin{array}{c}34 \\
3\end{array}$ & 90 & $\begin{array}{c}23 \\
4\end{array}$ & $\begin{array}{c}16 \\
1\end{array}$ & $\begin{array}{c}41 \\
8\end{array}$ & $\begin{array}{c}2,4 \\
1\end{array}$ & $\begin{array}{c}3,2 \\
4\end{array}$ \\
\hline $\begin{array}{l}\text { Otel inşaatları ve diğer turistik } \\
\text { yapılar, doğal çevreyi tahrip } \\
\text { edecektir. }\end{array}$ & $\begin{array}{c}11 \\
4\end{array}$ & $\begin{array}{c}29 \\
6\end{array}$ & 72 & $\begin{array}{c}18 \\
7\end{array}$ & $\begin{array}{c}19 \\
8\end{array}$ & $\begin{array}{c}51 \\
4\end{array}$ & $\begin{array}{c}1,3 \\
4\end{array}$ & $\begin{array}{c}3,3 \\
4\end{array}$ \\
\hline
\end{tabular}

"Turizm, suç oranlarını artıracaktır." ifadesinde katılımcıların çoğunluğu (n:192) katılmıyorum yönünde cevap vermiştir. Araştırmaya katılan öğrenciler, turizm ve suç oranlarının arasında ilişki olmadığ 1 kanaatindedirler. "Turizm ildeki terör ve diğer sosyal sorunları arttıracaktır" ifadesinde katılımcıların çoğunluğu (n:218) katılmıyorum ifadesini seçmiştir. Araştırmaya katılan öğrencilere göre, turizm bölgedeki terör ve diğer sorunları arttırmayacaktır. "Turizm, ilde aşırı nüfus artışına neden olacaktır" ifadesinde katılımcıların çoğunluğu (n:182) katılıyorum ifadesini seçmiştir. Araştırmaya katılan ögrenciler, turizmin bölgede nüfus artışına neden olacağına inanmaktadırlar. "Turizm ildeki pek çok mal ve hizmetin fiyat artışına neden olacaktır" ifadesinde katılımcıların çoğunluğu (n:227) katılıyorum ifadesini seçmiştir. Araştırmaya katılan öğrenciler, turizmin bölgedeki mal ve hizmetin fiyatının yükselteceği 
inancını taşımaktadırlar. "Turizm gürültü kirliliğine neden olacaktır" ifadesine katılımcıların çoğunluğu (n:189) katılıyorum ifadesini seçmiştir. "Turizm ildeki emlak fiyatlarının ve kiraların artmasına neden olacaktır" ifadesinde katılımcıların çoğunluğu (n:256) katılıyorum ifadesini seçmiştir. "Turizm ildeki alkol ve uyuşturucu kullanımını artıracaktır' ifadesinde katılımcıların çoğunluğu (n:161) katılıyorum ifadesini seçmiştir. Araştırmaya katılan öğrencilerin turizmin alkol ve uyuşturucu kullanımını artıracağ 1 yönünde düşüncesi mevcuttur. Turizm işletmelerinde alkol ürünlerinin satılması bu algının doğruluğunu destekler niteliktedir. "Otel inşaatları ve diğer turistik yapılar, doğal çevreyi tahrip edecektir" ifadesine katılımcıların çoğunluğu (n:198) katılıyorum cevabı vermiştir. Araştırmaya katılan öğrencilerin, otel inşaatlarının doğal çevreye tahribatta bulunacağ 1 yönünde endişesi mevcuttur. Tablo genel olarak değerlendirildiğinde katılımcıların çoğunlukla turizmin olumsuz sonuçlar yaratacağ 1 yönündeki ifadelere katılmıyorum yönünde cevap verdiği görülmektedir. Emlak fiyatlarının ve kiraların artması, inşaatların çevreye zarar vermesi ve alkol kullanımının artması gibi konularda ise öğrencilerin endişeliolduğu ya da kararsız olduğu göze çarpmaktadır.

Tablo 4. Cinsiyet Değişkeni İçin Farklılık Analizi (T Testi)

\begin{tabular}{|l|l|c|c|c|c|c|}
\hline \multicolumn{1}{|c|}{ Boyutlar } & Cinsiyet & $\mathbf{N}$ & $\begin{array}{c}\text { Ortala } \\
\text { ma }\end{array}$ & $\begin{array}{c}\text { Standa } \\
\text { rt } \\
\text { sapma }\end{array}$ & t & $\begin{array}{c}\text { Anlamlı } \\
\text { llk } \\
\text { düzeyi }\end{array}$ \\
\cline { 1 - 6 } $\begin{array}{l}\text { Turizmin } \\
\text { Olumsuz } \\
\text { Sonuçları }\end{array}$ & Kadın & 201 & 3,12 & 0,767 &, 217 & \multirow{2}{*}{0,413} \\
\cline { 2 - 6 } & Erkek & 184 & 3,10 & 0,820 &, 216 & \\
\hline $\begin{array}{l}\text { Turizmin } \\
\text { Olumlu } \\
\text { Sonuçları }\end{array}$ & Kadın & 201 & 3,87 & 0,622 & 2,355 & \multirow{2}{*}{0,000} \\
\cline { 2 - 6 } & Erkek & 184 & 3,69 & 0,854 & 2,323 & \\
\hline
\end{tabular}

Turizmin olumsuz sonuçları kapsamında dağılıma bakıldığında kadınların ortalaması erkeklere oranla biraz fazladır. Turizmin olumsuz sonuçları kapsamında erkekler ve kadınlar arasında (sig. 0,413) anlamlı farklıl1k bulunmamaktadır. Turizmin olumlu sonuçları boyutunda, kadınların ortalaması erkeklerin ortalamasından fazladır. Kadınlar erkeklere göre turizmin olumlu sonuçları olduğuna daha fazla inanmaktadır (sig. 0,000).

Tablo 5. Yaş Değişkeni İçin Farklılık Analizi (ANOVA Testi)

\begin{tabular}{|c|c|c|c|c|c|c|}
\hline Boyutlar & Yaş & N & Ortalama & $\begin{array}{c}\text { Standart } \\
\text { sapma }\end{array}$ & F & $\begin{array}{c}\text { Anlamlı̈ık } \\
\text { düzeyi }\end{array}$ \\
\hline
\end{tabular}




\begin{tabular}{|c|c|c|c|c|c|c|}
\hline \multirow{5}{*}{$\begin{array}{l}\text { Turizmin } \\
\text { Olumsuz } \\
\text { Sonuçları }\end{array}$} & $\begin{array}{l}18 \text { yaş } \\
\text { altı }\end{array}$ & 3 & 4,48 & 1,589 & \multirow{5}{*}{2,644} & \multirow{5}{*}{0,033} \\
\hline & $18-20$ yaş & 134 & 3,12 & 0,792 & & \\
\hline & 21-23 yaş & 194 & 3,07 & 0,755 & & \\
\hline & 24-28yaş & 49 & 3,21 & 0,854 & & \\
\hline & $\begin{array}{l}28 \text { yaş } \\
\text { üzeri }\end{array}$ & 5 & 3,00 & 0,467 & & \\
\hline \multirow{5}{*}{$\begin{array}{l}\text { Turizmin } \\
\text { Olumlu } \\
\text { Sonuçları }\end{array}$} & $\begin{array}{ll}18 & \text { yaş } \\
\text { altı } & \\
\end{array}$ & 3 & 2,85 & 0,500 & \multirow{5}{*}{1,348} & \multirow{5}{*}{0,252} \\
\hline & 18-20 yaş & 134 & 3,81 & 0,734 & & \\
\hline & 21-23yaş & 194 & 3,79 & 0,764 & & \\
\hline & 24-28 yaş & 49 & 3,72 & 0,710 & & \\
\hline & $\begin{array}{l}28 \text { yaş } \\
\text { üzeri }\end{array}$ & 5 & 3,90 & 0,699 & & \\
\hline
\end{tabular}

Yaş değişkeni açısından değerlendirildiğinde grupların ortalamalarının birbirine yakın değerler aldığı görülmektedir. Anlamlılık düzeyine bakıldığında turizmin olumsuz sonuçları açısından (sig. ,033) anlamlı farklılık elde edilmiştir. $\mathrm{Bu}$ farklılıkların hangi gruplardan kaynaklandığını öğrenmek için Post Hoc bölümündeki çoklu karşılaştırma analizlerinden faydalanılmıştır. $\mathrm{Bu}$ test sonucunda 18 yaşından küçük katılımcıların 18-20 yaş grubundaki katılımcılara oranla turizmin olumsuz sonuçları algısı daha yüksektir. 18 yaşından küçük katılımcıların turizmin olumsuz sonuçları algısı 21-23 yaş grubundaki katılımcılara oranla daha yüksektir. Yani genel olarak yaşı küçük olan katılımcılar turizmin olumsuz sonuçlarının fazla olduğuna inanmaktadır. Turizmin olumlu sonuçları açısından yaş değiş̧kenine göre anlamlı farklılık bulunmamıştır (sig. ,252).

Tablo 6. Turizm Sektörü Deneyimi Değişkeni İçin Farklılık Analizi (T Testi)

\begin{tabular}{|l|l|c|c|c|c|c|}
\hline Boyutlar & $\begin{array}{c}\text { Sektör } \\
\text { deneyimi }\end{array}$ & N & $\begin{array}{c}\text { Ortala } \\
\text { ma }\end{array}$ & $\begin{array}{c}\text { Standa } \\
\text { rt } \\
\text { sapma }\end{array}$ & t & $\begin{array}{c}\text { Anlamlı } \\
\text { lık } \\
\text { düzeyi }\end{array}$ \\
\hline $\begin{array}{l}\text { Turizmin } \\
\begin{array}{l}\text { Olumsuz } \\
\text { Sonuçlar1 }\end{array}\end{array}$ & Yar & 48 & 3,14 & 0,816 &, 215 & \multirow{2}{*}{0,564} \\
\cline { 2 - 6 } $\begin{array}{l}\text { Turizmin } \\
\begin{array}{l}\text { Olumlu } \\
\text { Sonuçlar1 }\end{array}\end{array}$ & Var & 337 & 3,11 & 0,790 &, 210 & \\
\cline { 1 - 6 } & Yok & 337 & 3,80 & 0,725 &,- 567 & \multirow{2}{*}{0,057} \\
\hline
\end{tabular}


Turizmin olumsuz sonuçları için sektör deneyimi bazında anlamlı farklılıklar bulunmamıştır (sig. ,564). Ortalamalara bakıldığında turizm sektörü deneyimi olanlar ve olmayanlar birbirine yakın değerler almıştır. Turizmin olumlu sonuçlarına bakıldığında anlamlı farklılık bulunmamış ortalamalar ise birbirine yakın değerler almıştır (sig. ,057). Öğrencilerin turizm sektöründe sahip oldukları deneyim, öğrencilerin turizmin olumlu ve olumsuz sonuçlarına ilişkin algılarında anlamlı bir farklılığın oluşmasını etkilememektedir. Sektörde çalışmış olan öğrencilerin turizm algıları ile sektörde çalışmamış öğrencilerin turizm algısının benzer olması dikkat çekici bir bulgudur. Bu durumun sektörde çalışmamış olan kişilerinde en az çalışmış kişiler kadar sektörle ilişki içinde olmasından kaynaklandığı düşünülmektedir. Çünkü turizm insanların hizmetin üretildiği yere bizzat gelmesini ve gözlemler yapabilmesine olanak sağlayan bir sektördür.

Tablo 7. Van'da İkamet Süresi Değişkeni İçin Farklılık Analizi (ANOVA Testi)

\begin{tabular}{|c|c|c|c|c|c|c|}
\hline Boyutlar & $\begin{array}{c}\text { İkamet } \\
\text { Süresi }\end{array}$ & $\mathbf{N}$ & $\begin{array}{c}\text { Ortala } \\
\text { ma }\end{array}$ & $\begin{array}{c}\text { Standa } \\
\text { rt } \\
\text { sapma }\end{array}$ & $\mathbf{F}$ & $\begin{array}{l}\text { Anlamlı } \\
\text { lık } \\
\text { düzeyi }\end{array}$ \\
\hline \multirow{4}{*}{$\begin{array}{l}\text { Turizmin } \\
\text { Olumsuz } \\
\text { Sonuçları }\end{array}$} & $\begin{array}{l}1 \text { yıldan } \\
\text { az }\end{array}$ & 79 & 3,08 & 0,758 & \multirow{4}{*}{1,495} & \multirow{4}{*}{0,215} \\
\hline & 1-3 yıl & 114 & 3,07 & 0,806 & & \\
\hline & $3-6$ & 77 & 3,28 & 0,675 & & \\
\hline & $\begin{array}{l}6 \text { yıldan } \\
\text { fazla }\end{array}$ & 115 & 3,06 & 0,864 & & \\
\hline \multirow{4}{*}{$\begin{array}{l}\text { Turizmin } \\
\text { Olumlu } \\
\text { Sonuçları }\end{array}$} & $\begin{array}{l}1 \text { yıldan } \\
\text { az }\end{array}$ & 79 & 3,74 & 0,729 & \multirow{4}{*}{3,538} & \multirow{4}{*}{0,015} \\
\hline & 1-3 yıl & 114 & 3,71 & 0,801 & & \\
\hline & 3-6 & 77 & 3,67 & 0,701 & & \\
\hline & $\begin{array}{l}6 \text { yıldan } \\
\text { fazla }\end{array}$ & 115 & 3,97 & 0,706 & & \\
\hline
\end{tabular}

Turizmin olumsuz sonuçlarına ikamet süresi bazında bakıldığında ortalaması en fazla olan ikamet süresi 3-6 yıl arasında değişen katılımcılara aittir. Turizmin olumsuz sonuçları ikamet süresine göre anlamlı farklılık göstermemektedir. Turizmin olumlu sonuçlarına ikamet süresi açısından bakıldığında anlamlı farklılık olduğu görülmektedir (sig. ,015). Anlamlılığın hangi gruplardan kaynaklandığını belirlemek amacıyla yapılan Post Hoc analizi sonucunda, 6 yıldan daha fazla süredir Van'da ikamet eden katılımciların olumlu turizm algıları 1-3 yıl ve 3-6 yıl süre ile ikamet eden katılımcıların algısından daha yüksektir.

Tablo 8. Aylık Harcama Değişkeni İçin Farklılık Analizi (ANOVA Testi) 


\begin{tabular}{|c|c|c|c|c|c|c|}
\hline Boyutlar & $\begin{array}{c}\text { Aylık } \\
\text { harcama }\end{array}$ & $\mathbf{N}$ & $\begin{array}{c}\text { Ortalam } \\
\mathbf{a}\end{array}$ & $\begin{array}{c}\text { Standa } \\
\text { rt } \\
\text { sapma } \\
\end{array}$ & $\mathbf{F}$ & $\begin{array}{c}\text { Anlamlıl } \\
\text { lk } \\
\text { düzeyi } \\
\end{array}$ \\
\hline \multirow{5}{*}{$\begin{array}{l}\text { Turizmin } \\
\text { Olumsuz } \\
\text { Sonuçları }\end{array}$} & 500 ve altı & 189 & 3,09 & 0,746 & \multirow{5}{*}{0,417} & \multirow{5}{*}{0,796} \\
\hline & $500-1000$ & 132 & 3,16 & 0,867 & & \\
\hline & $1000-1500$ & 42 & 3,07 & 0,626 & & \\
\hline & $1500-2000$ & 12 & 2,94 & 1,172 & & \\
\hline & $\begin{array}{l}2000 \text { ve } \\
\text { üzeri }\end{array}$ & 9 & 3,25 & 0,714 & & \\
\hline \multirow{5}{*}{$\begin{array}{l}\text { Turizmin } \\
\text { Olumlu } \\
\text { Sonuçları }\end{array}$} & 500 ve altı & 189 & 3,86 & 0,684 & \multirow{5}{*}{2,804} & \multirow{5}{*}{0,026} \\
\hline & $500-1000$ & 132 & 3,64 & 0,827 & & \\
\hline & $1000-1500$ & 42 & 3,89 & 0,646 & & \\
\hline & $1500-2000$ & 12 & 4,02 & 0,639 & & \\
\hline & $\begin{array}{l}2000 \text { ve } \\
\text { üzeri }\end{array}$ & 9 & 3,45 & 1,039 & & \\
\hline
\end{tabular}

Turizmin olumsuz sonuçlarının aylık harcama bazında dağılımına bakıldığında en yüksek ortalama 3,25 tir. Turizmin olumsuz sonuçları arasında anlamı farklılık bulunmamıştır (sig. ,796). Turizmin olumlu sonuçlarının aylık harcama açısından dağılımında ise en yüksek ortalama 4,02 olarak hesaplanmıştır. Turizmin olumlu sonuçları açısından anlamlı farklılık tespit edilmiştir (sig. ,026). Anlamlılı̆̆ın hangi gruplardan kaynaklandığını belirlemek amaciyla yapılan Post Hoc analizi sonucunda, 500 TL altında aylık harcama yapan katılımcıların turizmin olumlu sonuçları algısı 500-1000 TL harcama yapan katılımcıların algısından yüksektir.

Tablo 9. Babanın eğitim durumu İçin Farklılık Analizi (ANOVA Testi)

\begin{tabular}{|c|c|c|c|c|c|c|}
\hline Boyutlar & $\begin{array}{c}\text { Eğitim } \\
\text { durumları }\end{array}$ & $\mathbf{N}$ & $\begin{array}{c}\text { Ortala } \\
\text { ma }\end{array}$ & $\begin{array}{c}\text { Standa } \\
\text { rt } \\
\text { sapma }\end{array}$ & $\mathbf{F}$ & $\begin{array}{c}\text { Anlamlı } \\
\text { lık } \\
\text { düzeyi }\end{array}$ \\
\hline \multirow{5}{*}{$\begin{array}{l}\text { Turizmin } \\
\text { Olumsuz } \\
\text { Sonuçları }\end{array}$} & İlköğretim & 243 & 3,10 & 0,817 & \multirow{5}{*}{0,460} & \multirow{5}{*}{0,765} \\
\hline & Lise & 75 & 3,10 & 0,704 & & \\
\hline & Ön lisans & 16 & 3,23 & 0,726 & & \\
\hline & Lisans & 32 & 3,19 & 0,843 & & \\
\hline & $\begin{array}{l}\text { Yüksek } \\
\text { lisans ve } \\
\text { doktora }\end{array}$ & 8 & 2,81 & 0,802 & & \\
\hline \multirow{4}{*}{$\begin{array}{l}\text { Turizmin } \\
\text { Olumlu } \\
\text { Sonuçları }\end{array}$} & İlköğretim & 243 & 3,79 & 0,746 & \multirow{4}{*}{1,837} & \multirow{4}{*}{0,121} \\
\hline & Lise & 75 & 3,90 & 0,595 & & \\
\hline & Ön lisans & 16 & 4,08 & 0,629 & & \\
\hline & Lisans & 32 & 3,74 & 0,773 & & \\
\hline
\end{tabular}




\begin{tabular}{|l|l|l|l|l|l|l|}
\hline & $\begin{array}{l}\text { Yüksek } \\
\text { lisans ve } \\
\text { doktora }\end{array}$ & 8 & 3,34 & 0,936 & & \\
\hline
\end{tabular}

Turizmin olumsuz sonuçları babanın eğitim durumu bazında incelendiğinde, en yüksek ortalama 3,23 olarak hesaplanmıştır. Turizmin olumsuz sonuçları arasında anlamlı farklılık bulunmamıştır (sig. ,765). Turizmin olumlu sonuçları arasında en yüksek ortalama 4,08 ile babası önlisans mezunu olan katılımcilara aittir. Turizmin olumlu sonuçları açısından da anlamlı farklılık bulunmamıştır (sig. ,121).

Tablo 10. Annenin eğitim durumu İçin Farklılık Analizi (ANOVA Testi)

\begin{tabular}{|c|c|c|c|c|c|c|}
\hline Boyutlar & $\begin{array}{c}\text { Ĕgitim } \\
\text { durumları }\end{array}$ & $\mathbf{N}$ & Ortalama & $\begin{array}{c}\text { Standart } \\
\text { sapma }\end{array}$ & $\mathbf{F}$ & $\begin{array}{c}\text { Anlamlılık } \\
\text { düzeyi }\end{array}$ \\
\hline \multirow{5}{*}{$\begin{array}{l}\text { Turizmin } \\
\text { Olumsuz } \\
\text { Sonuçları }\end{array}$} & İlköğretim & 266 & 3,12 & 0,812 & \multirow{5}{*}{0,051} & \multirow{5}{*}{0,995} \\
\hline & Lise & 33 & 3,11 & 0,760 & & \\
\hline & Ön lisans & 9 & 3,22 & 0,949 & & \\
\hline & Lisans & 5 & 3,20 & 0,730 & & \\
\hline & $\begin{array}{l}\text { Yüksek } \\
\text { lisans ve } \\
\text { doktora }\end{array}$ & 2 & 3,03 & 0,114 & & \\
\hline \multirow{5}{*}{$\begin{array}{l}\text { Turizmin } \\
\text { Olumlu } \\
\text { Sonuçları }\end{array}$} & İlköğretim & 266 & 3,80 & 0,717 & \multirow{5}{*}{1,406} & \multirow{5}{*}{0,232} \\
\hline & Lise & 33 & 3,82 & 0,687 & & \\
\hline & Ön lisans & 9 & 4,08 & 0,615 & & \\
\hline & Lisans & 5 & 3,72 & 0,458 & & \\
\hline & $\begin{array}{l}\text { Yüksek } \\
\text { lisans ve } \\
\text { doktora }\end{array}$ & 2 & 2,78 & 0,909 & & \\
\hline
\end{tabular}

Turizmin olumsuz sonuçları annenin eğitim durumu bazında incelendiğinde, en yüksek ortalama 3,22 ile annesi ön lisans mezunu olanlara aittir. Turizmin olumsuz sonuçları arasında anlamlı farklılık bulunmamıştır (sig. ,995). Turizmin olumlu sonuçları arasında en yüksek ortalama 4,08 dir. Turizmin olumlu sonuçları arasında da istatistiksel olarak anlamlı farklılık bulunmamıştır (sig. ,232).

\section{SONUÇ VE ÖNERILER}

Turizmin olumlu ve olumsuz etkileri ile ilgili yapılmış daha önceki bazı çalışmalara göre (Alaeddinoğlu, 2008: 239; Toprak 2015) yerel halk turizmin 
olas1 olumsuz etkilerini algılanmasına rağmen, turizmin olumlu etkilerinin ağırlıkta olacağı düşüncesiyle turistlere karşı olumlu düşüncelere sahiptir. Benzer bir sonuç üniversite öğrencilerine yönelik olarak yapılan bu araştırmada da elde edilmiştir. Öğrenciler, turizmin olumsuz sonuçlarının varlığının farkında ancak turizmin olumlu sonuçlarının daha ağır bastığını düşünmektedir. Turizmin olumlu sonuçlarına ilişkin ifadelere verilen yanıtların genel ortalaması 3,79 ile katılıyorum yönünde iken, turizmin olumsuz sonuçlarına ilişkin ifadelere verilen yanıtların genel ortalaması 3,11 olarak hesaplanmıştır. Araştırmaya katılan öğrencilere göre turizmin Van için ortaya çıaracağı olumsuz sonuçlarından en önemlileri fiyatların artması ve kiraların artması olacaktır.

Araştırma kapsamında turizme ilişkin olumlu ve olumsuz algının demografik özelliklere göre farklılık gösterip göstermediği test edilmiştir. Bu kapsamda bazı demografik özelliklere göre anlamlı farklılıklar elde edilmiştir. Turizmin olumlu sonuçları kapsamında, kadınların algısı erkeklerden farklılık göstermiştir. Kadınlar turizmin olumlu sonuçları olduğuna erkeklere göre daha fazla inanmaktadır. Yaş değişkeni açısından da turizmin olumsuz sonuçları kapsamında farklılık tespit edilmiştir. 18 yaşından küçük katılımcıların turizmin olumsuz sonuçları algısı, 21-23 yaş grubundaki katılımcılara oranla daha yüksektir. Yani genel olarak yaşı küçük olan katılımcılar, turizmin olumsuz sonuçlarının fazla olduğuna inanmaktadır. $\mathrm{Bu}$ sonuç yaşı küçük olan katılımcıların sahip olduğu önyargı ile ilişkilendirilebilir. Turizmin olumlu sonuçlarına ikamet süresi açısından bakıldığında anlamlı farklılık olduğu görülmektedir. Anlamlılığın hangi gruplardan kaynaklandığını belirlemek amaciyla yapılan Post Hoc analizi sonucunda, 6 yıldan daha fazla süredir Van'da ikamet eden katılımcıların olumlu turizm algıları 1-3 yıl ve 3-6 yıl süre ile ikamet eden katılımcıların algısından daha yüksektir. Yani 6 yıldan fazla süredir Van'da ikamet eden katılımcılar diğer gruplara kıyasla turizmin olumlu sonuçlarının daha fazla olduğuna inanmaktadır. Aylık harcama değişkenine göre turizmin olumlu sonuçları açısından anlamlı farklılık tespit edilmiştir. 500 TL altında aylık harcama yapan katılımcıların turizmin olumlu sonuçları algısı 500-1000 TL harcama yapan katılımcıların algısından daha yüksektir.

Yapılan araştırma kapsamında elde edilen veriler ışığında aşağıda belirtilen öneriler ilgililere sunulabilir;

1- Üniversite öğrencileri turizm sektörünün dünyada sahip olduğu konum ve önem konularında eğitilmelidir.

2- Öğrencilerin turizm konusundaki duyarlılıkları göz önüne alınarak çevreyle uyumlu ve sürdürülebilir projeler geliştirilmelidir. 
3- Çevreye duyarl1, sürdürülebilir bir turizm gelişiminin gerçekleştirilebilmesi için önemli bir paydaş olan üniversite öğrencilerinin algıları ve tutumları düzenli aralıklarla ölçülmeli ve değerlendirilmelidir.

4- Kamu kuruluşları turizme yönelik uyguladığı proje ve yatırımlar için öğrencilerin desteğini almayı önemsemelidir. Bu yatırımlar esnasında turizmin olumlu ve olumsuz sonuçları dikkate alınmalıdır.

5- Öğrencilerin turizme ilişkin önyargılarını yıkmak için, öğrencilerin turizm faaliyetlerine dahil olmasını sağlayacak girişimlerde bulunulmalıdır.

\section{KAYNAKLAR}

Akova, Orhan (2006). "Yerel Halkın Turizmin Etkilerini Algılamalarına ve Tutumlarına Yönelik Bir Araştırma", Akademik İncelemeler Dergisi, 2(1).

Alaeddinoğlu, Faruk (2008). "Sivas Kentinde Halkın Turiste ve Turizme

Bakışı", Uluslararası İnsan Bilimleri Dergisi, 5(2), ss. 1-23.

Arslan Kalay, Hacer., Şahin, Sedat ve Meriç, Sağbetullah. (2018). "Mimari Mirasın Turizme Açılmasının Mimari Mirasın Korunmasına Etkisi: Sanat Tarihi ve Turizm Öğrencilerine Yönelik Bir Araştırma", Ordu Sosyal Bilimler Araştırmaları Dergisi (ODÜSOBİAD), 8(1), ss. 65-78.

Arslan Kalay, Hacer ve Yıldız, Sevcan (2017). "Akdamar Anıt Müzesi'nin (Kilisesi) Tarihsel Süreçleri ve Kültürel Miras Turizmi Açısından Önemi", Bitlis Eren Üniversitesi Sosyal Bilimler Enstitüsü Dergisi, 6(1), ss. 121-136.

Bilgin, Leman ve Özdemir, Aytül (2013). Davranış Bilimleri, Anadolu Üniversitesi Yayınları, Eskişehir.

Cengiz, Ekrem ve Kırkbir, Fazıl (2007). "Yerel Halk Tarafindan Algılanan Toplam Turizm Etkisi İle Turizm Desteği Arasındaki İlişkiye Yönelik Yapısal Bir Model Önerisi", Sosyal Bilimler Dergisi, 1, ss.19-37.

Civelek, Ayşen (2010). "Turizmin Sosyal Yapıya ve Sosyal Değişmeye Etkileri". Selçuk Üniversitesi Sosyal Bilimler Myo Dergisi, 13(1-2), ss. 331-350.

Cook, Roy., Hsu, Cathy. H. ve Marqua, Joseph (2016). Tourism: The Business of Hospitality and Travel. Pearson Press. 
DAKA (2013). TRB2 Bölgesi Mevcut Durum Analizleri (Taslak Rapor), DAKA, Van.

De Kadt, Emanuel (1979). Tourism: Passport to Development. Oxford University Press, New York/London.

Eralp, Ziya. (1983). Genel Turizm. Ankara Üniversitesi Yayınları, Ankara.

Goeldner, Charles. R. ve Ritchie, Brent (2009). Tourism Principles, Practices, Philosophies. john Wiley and Sons, New York.

Gümüş, Nevzat ve Özüpekçe, Salman (2009). "Foça'da Turizmin Ekonomik, Sosyal, Kültürel Ve Çevresel Etkilerine Yönelik Yerel Halkın Görüssleri", Uluslararası İnsan Bilimleri Dergisi, 6(2), ss.398-417.

Inskeep, Edward (1991). Tourism Planning: An Integrated and Sustainable Approach. Van Nostrand Reinhold, New York.

Işık, Cem. ve Meriç, Sağbetullah (2015). "Otel Yöneticilerinin Bireysel Yenilikçi Kapsamında Değerlendirilmesi: Van İli Örneği". Girişimcilik ve İnovasyon Yönetimi Dergisi, 4(1), ss.1-16.

Karakaş, Ayhan ve Şengün, Halil İ. (2017). "Yerel Halkın Turizm Faaliyetlerine Yönelik Tutumları", İktisadi ve İdari Bilimler Fakültesi Dergisi, 30, ss.183-202.

Kaya, Fazıl., Cankül, Duran ve Demirci, Barış. (2013). "Türkiye'nin Önemli İnanç Turizmi Merkezlerinden Biri: Akdamar Kilisesi", Karamanoğlu Mehmetbey Üniversitesi Sosyal ve Ekonomik Araştırmalar Dergisi, 15(24), ss. $13-24$.

Kozak, Metin A. (2012). Genel Turizm Bilgisi. Anadolu Üniversitesi Yayınları, Eskişehir.

Long, Patrick. T. ve Richardson, Sarah L. (1989). "Integrating Recreation and Tourism Development in Small Winter Cities", Journal of Physical Education, Recreation \& Dance, 60(8), ss. 58-61.

Meriç, Sağbetullah ve Bozkurt, Öznur (2017). "Van Gölü'nün Rekreasyonel Turizm Potansiyelinin SWOT Analizi İle Değerlendirilmesi", Uluslararası Kültürel ve Sosyal Araştırmalar Dergisi, 3(1), ss.154-167.

Odabaşı, Ersin ve Tekbaş, Ömer. F. (2015). "Van Gölü Suyu Tedavi Amacıyla Kullanılabilir Mi?", TAF Preventive Medicine Bulletin, 14(1), ss.71-74. 
Okuyucu, Ayşe ve Somuncu, Mehmet (2012). "Kültürel Mirasın Korunması ve Turizm Amaçı Kullanılmasında Yerel Halkın Algı ve Tutumlarının Belirlenmesi: Osmaneli İlçe Merkezi Örneği", Ankara Üniversitesi Çevrebilimleri Dergisi, 4(1), ss.37-51.

Sheldon, Pauline. J. ve Var, Turgut (1984). "Residents Attitudes to Tourism in North Wales", Tourism Management, 5(1), ss. 40-48.

Toprak, Lokman (2015). "Mardin'de Yerel Halkın Turizm Algısı", Elektronik Sosyal Bilimler Dergisi, 14(54), ss. 201-218.

Türker, Gülay. Ö. ve Türker, Ali (2015). "Yerel Halkın Turizm Etkilerini Algılama Düzeyi Turizm Desteğini Nasıl Etkiler: Dalyan Destinasyonu Örneği", Ejovoc (Electronic Journal of Vocational Colleges), 4(1), ss. 8198.

Van Kültür Turizm Müdürlüğü (2018). http://www.vankulturturizm.gov.tr/ TR,90249/tarihi-yapi.html (Erişim Tarihi: 02.04.2018)

Zengin, Burhanettin (2010). "Turizm Sektörünün Türkiye Ekonomisine Reel Ve Moneter Etkileri", Akademik İncelemeler Dergisi, 5(1), ss. 102-126. 